\title{
EKSPERIMENTASI PEMBELAJARAN MATEMATIKA DENGAN PENDEKATAN REALISTIC MATHEMATICS EDUCATION (RME) DAN PROBLEM POSING DITINJAU DARI GAYA BELAJAR SISWA DI SMP NEGERI 8 TEBING TINGGI
}

\author{
Basir Purba \\ Surel : basirpurba24@gmail.com
}

\begin{abstract}
ABSTRAK
Penelitian ini merupakan penelitian eksperimental semu dengan desain faktorial $2 \times 3$. Populasi dari penelitian ini adalah seluruh siswa Kelas VIII SMP Negeri 8 Tebing Tinggi. Pengambilan sampel dilakukan dengan stratified cluster random sampling. Sampel dalam penelitian ini berjumlah 188 orang dengan rincian 97 orang untuk kelas eksperimen 1 dan 91 orang untuk kelas eksperimen 2. Instrumen yang digunakan untuk mengumpulkan data adalah tes prestasi belajar matematika dan angket gaya belajar siswa. Uji keseimbangan menggunakan uji rerata t, dengan $\alpha=0,05$ diperoleh kesimpulan bahwa kedua kelompok eksperimen dalam keadaan seimbang.
\end{abstract}

Kata kunci: Realistic Mathematics Education, Problem Posing

\section{PENDAHULUAN}

Matematika merupakan ilmu pengetahuan yang sangat berguna untuk menyelesaikan permasalahan dalam kehidupan sehari-hari. Matematika juga merupakan dasar untuk memahami ilmu pengetahuan lainnya, seperti fisika dan kimia. Hal inilah yang menyebabkan matematika dijadikan mata pelajaran wajib di setiap jenjang pendidikan formal. Matematika diajarkan pertama kali dalam pendidikan formal yaitu pada tingkat dasar (SD dan SMP). Salah satu faktor yang mempengaruhi rendahnya prestasi belajar matematika siswa adalah ketakutan siswa terhadap matematika. Peker, M (2008) mengatakan bahwa: "Students' low success level in mathematics has been a worry for a long time in many countries. There are a lot of factors affecting success in mathematics. One of these factors is students' mathematical anxiety, in other words, their mathematical fear". Sudah sejak dulu rendahnya prestasi belajar matematika siswa menjadi salah satu kekhawatiran di banyak negara. Banyak faktor yang mempengaruhi kesuksesan belajar matematika. Salah satu dari faktor tersebut adalah ketakutan pada matematika. Ketakutan pada matematika adalah gabungan yang kompleks dari dimensi afektif dan kognitif. Kepribadian, konsep diri, harga diri, gaya belajar, pola asuh orang tua, tuntutan yang tinggi dari orang tua, sikap negatif pada matematika, menghindari matematika, sikap guru, gaya belajar yang tidak efektif, pengalaman belajar yang negatif dan penghargaan yang kurang adalah konsep 
Basir Purba : Eksperimentasi Pembelajran Mate ....

dan konstruksi yang berhubungan dengan ketakutan terhadap matematika.

Menurut data yang diperoleh

Dinas Pendidikan Kota Tebing Tinggi, hasil ujian nasional SMP Negeri di Kota Tebing Tinggi pada tahun ajaran 2013/2014 dan 2014/2015 menunjukkan bahwa nilai rata-rata Matematika berada pada posisi ketiga setelah Bahasa Indonesia dan IPA. Pada tahun ajaran 2013/2014 nilai rata-rata Bahasa Indonesia $(7,25)$, IPA $(6,91)$ dan Matematika $(6,11)$ sementara pada tahun ajaran 2014/2015 nilai rata-rata Bahasa Indonesia $(7,15)$, IPA $(6,87)$ dan Matematika $(5,91)$. Hal ini menunjukkan bahwa masih banyak siswa yang mengalami kesulitan dalam matematika dibandingkan dengan pelajaran lainnya. Dalam perkembangan paradigma pembelajaran, guru masih sering merasa bingung dan kesulitan dalam menentukan atau menggunakan pendekatan pembelajaran yang akan digunakan. Setiap pendekatan pembelajaran yang dikembangkan selalu memiliki kelebihan, akan tetapi tidak semua pendekatan pembelajaran akan cocok digunakan dalam semua materi pelajaran. Keberagaman gaya belajar dan kemampuan siswa dalam menerima pembelajaran juga turut andil dalam penentuan pendekatan pembelajaran yang akan digunakan oleh guru. Salah satu pokok bahasan dalam mata pelajaran matematika yang dipelajari siswa SMP Kelas VIII semester 1 adalah kelipatan dan faktor. Kompetensi dasar dan hasil belajar yang harus dikuasai siswa dalam pokok bahasan ini adalah: mengenal kelipatan dan faktor bilangan, menyelesaikan masalah yang berkaitan dengan kelipatan persekutuan terkecil (KPK) dan faktor persekutuan terbesar (FPB). Biasanya kesulitan yang dialami adalah siswa kesulitan memahami konsep kelipatan dan faktor suatu bilangan, sulit mentransformasikan soal-soal cerita yang berhubungan dengan KPK dan FPB ke dalam bentuk matematika sehingga siswa sulit menemukan penyelesaian dari soal tersebut, karena biasanya guru mengajarkan materi ini dengan memberikan rumus-rumus sebagai patokan dalam mengerjakan soal yang berkaitan dengan kelipatan dan faktor, sementara siswa tidak memahami maknanya. Dengan memilih pendekatan pembelajaran yang tepat diharapkan kesulitankesulitan yang dihadapi siswa selama ini dapat teratasi. Realistic Mathematics Education (RME) merupakan salah satu pendekatan pembelajaran matematika. Teori RME pertama kali diperkenalkan dan dikembangkan di Belanda pada tahun 1970 oleh Institut Freudenthal. Teori ini mengacu pada pendapat Freudenthal yang mengatakan bahwa matematika harus dikaitkan dengan realita dan matematika merupakan aktivitas manusia. Ini berarti matematika harus dekat dengan anak dan relevan dengan kehidupan nyata sehari-hari. Matematika sebagai aktivitas manusia berarti manusia 
harus diberi kesempatan untuk menemukan kembali ide dan konsep matematika dengan bantuan orang dewasa. (I Gusti Putu Suharta, 2002).RME mempunyai lima karakteristiksebagai berikut :

a. Menggunakan masalah kontekstual (sebagai aplikasi dan titik tolak dari mana matematika yang diinginkan muncul).

b. Menggunakan model atau jembatan dengan instrumen vertikal (perhatian diarahkan pada pengembangan model, skema dan simbolisasi daripada hanya mentransfer rumus atau matematika formal secara langsung).

c. Menggunakan kontribusi murid (kontribusi yang besar pada proses belajar mengajar diharapkan dari konstruksi murid sendiri yang mengarahkan mereka dari metode informal ke arah yang lebih formal atau standar).

d. Interaktivitas (negosiasi secara eksplisit, intervensi, kooperasi dan evaluasi sesama murid dan guru adalah faktor penting dalam proses belajar secara konstruktif dengan strategi informal muridigunakan sebagai jantung untuk mencapai yang formal).

e. Terintegrasi dengan topik pembelajaran lainnya (pendekatan holistik, menunjukkan bahwa unit-unit belajar tidak akan dapat dicapai secara terpisah, tetapi keterkaitan dan keterintegrasiannya harus dieksploitasi dalam pemecahan masalah).

Pendekatan problem posing adalah suatu pendekatan dalam pembelajaran matematika di mana siswa diminta untuk merumuskan, membentuk dan mengajukan pertanyaan atau soal dari situsi yang disediakan. Situasi dapat berupa gambar, cerita, atau informasi lain yang berkaitan dengan materi pelajaran.

Dalam pelaksanaanya menurut Zahra Chairani (2007) dikenal beberapa jenis model problem posing antara lain:

a. Situasi problem posing bebas, siswa diberikan kesempatan yang seluas-luasnya untuk mengajukan soal sesuai dengan apa yang dikehendaki. Siswa dapat menggunakan fenomena dalam kehidupan sehari-hari sebagai acuan untuk mengajukan soal.

b. Situasi problem posing semi terstruktur siswa diberikan situasi/informasi terbuka. Kemudian siswa diminta untuk mengajukan soal dengan mengkaitkan informasi itu dengan pengetahuan yang sudah dimilikinya. Situasi dapat berupa gambar atau informasi yang dihubungkan dengan konsep tertentu.

c. Situasi problem posing terstruktur, siswa diberi soal atau selesaian soal tersebut, kemudian berdasarkan hal tersebut siswa diminta untuk mengajukan soal baru. 
Setiap siswa mempunyai fungsi otak yang berbeda dan pemprosesan informasi mereka juga berbeda. Sehingga mereka juga memiliki gaya belajar yang berbeda pula. Jika guru dapat memahami kekurangan dan kelebihan gaya belajar siswa, mereka dapat beradaptasi dengan lebih baik. Gaya belajar adalah karakteristik kognitif, afektif dan perilaku psikologi yang mengindikasikan perasaan peserta didik, interaksi mereka dengan lingkungan belajar. Pada awal pengalaman belajar, langkah pertama yang harus dilakukan adalah mengenali modalitas seseorang, dalam hal ini adalah gaya belajar yaitu berdasarkan pada visual (penglihatan), auditorial (pendengarana), atau kinestetik (sentuhan dan gerakan) yang selanjutnya dikenal dengan nama modalitas V-A-K.

a. Gaya Belajar Visual: Siswa dengan gaya belajar visual, yang memegang peranan penting adalah mata/penglihatan (visual). Dalam hal ini metode pembelajaran yang digunakan oleh guru sebaiknya lebih banyak atau dititik beratkan pada peragaan atau media agar mereka langsung dapat melihat obyek-obyek yang berkaitan dengan pelajaran tersebut.

b. Gaya Belajar Auditorial: Siswa dengan gaya belajar auditorial mengandalkan kesuksesan belajarnya melalui telinga (alat pendengaran), misalnya mendengarkan ceramah atau penjelasan gurunya, mendengarkan bahan audio seperti kaset, CD dan sebagainya.

c. Gaya Belajar Kinestetik: Kecerdasan kinestetik memuat kemampuan seseorang untuk secara aktif menggunakan bagian-bagian atau seluruh tubuhnya untuk berkomunikasi dan memecahkan berbagai masalah.

\section{METODE PENELITIAN}

Penelitian ini dilaksanakan di SMP Negeri 8, yang meliputi 24 Kelas yang terdiri dari kelas Unggulan dan Non Unggulan, dengan subyek penelitian adalah siswa Kelas VIII semester ganjil Tahun Ajaran 2015/2016. Uji coba instrumen juga dilaksanakan di SMP Negeri 8 Tebing Tinggi. Penelitian yang dilaksanakan merupakan penelitian eksperimental semu. Dalam penelitian eksperimental semu yang melibatkan dua kelompok, kedua kelompok diasumsikan sama dalam semua segi, hanya berbeda dalam pendekatan pembelajarannya. Pada penelitian ini, pendekatan yang digunakan pada kelompok eksperimen 1 adalah pendekatan RME, sedangkan pendekatan pada kelompok eksperimen 2 pendekatan Problem Posing. Kedua pendekatan pembelajaran tersebut merupakan variabel bebas dari penelitian, sedangkan variabel bebas lain adalah gaya belajar siswa. Pada akhir penelitian, kedua kelompok diukur 
dengan menggunakan alat ukur yang sama yaitu soal-soal tes prestasi belajar matematika siswa. Hasil pengukuran tersebut dianalisis dan dibandingkan dengan tabel uji statistik yang digunakan.

Prosedur yang dilakukan dalam penelitian ini adalah:

a. Menentukan populasi;

b. Menentukan sampel secara stratified cluster random sampling, sampel dibagi menjadi dua kelompok yaitu kelompok eksperimen 1 dan kelompok eksperimen 2 kemudian melakukan uji keseimbangan pada kedua sampel tersebut untuk mengetahui apakah keduanya dalam keadaan seimbang;

c. Melakukan pengambilan data tentang gaya belajar siswa dengan angket yang dikategorikan menjadi tiga katagori kelompok siswa yaitu kelompok siswa dengan gaya belajar visual, gaya belajar auditorial dan gaya belajar kinestetik;

d. Kelompok eksperimen 1 diberikan pembelajaran dengan pendekatan RME sedangkan kelompok eksperimen 2 diberikan pembelajaran dengan pendekatan Problem Posing;

e. Melakukan tes prestasi belajar matematika untuk pokok bahasan kelipatan dan faktor;

f. Melakukan analisis data untuk mengetahui signifikansi perbedaan prestasi belajar siswa pada pokok bahasan kelipatan

dan faktor ditinjau dari
penggunaan pendekatan
pembelajaran yang berbeda,
gaya belajar dan interaksi
pendekatan pembelajaran dan
gaya belajar.

Populasi dalam penelitian ini adalah seluruh siswa Kelas VIII semester ganjil SMP Negeri 8 Tebing Tinggi, yang terdiri dari 24 Kelas yang terdiri kelas Unggulan dan Non Unggulan. Pada penelitian ini, peneliti mengambil sampel sebagian dari populasi, diharapkan hasil yang dicapai sudah dapat menggambarkan sifat dari populasi tersebut. Hasil penelitian ini akan digeneralisasi pada populasi.

Pengambilan sampel dilakukan secara stratified cluster random sampling pada SMP Negeri 8 Tebing Tinggi. Pertama dilakukan pengelompokan sekolah berdasarkan rangking sekolah yang didasarkan pada rata-rata nilai UASBN mata pelajaran matematika tahun pelajaran 2012/2013, 2013/2014 dan 2014/2015 menjadi 3 kelompok yaitu tinggi, rendah dan sedang. Selanjutnya dari masing-masing kelompok dipilih secara acak sebagai kelas eksperimen 1 dan kelas eksperimen 2. Setelah dipilih secara acak, didapatkan sampel kelas dari kelompok tinggi adalah VIII-3 dan VIII -1. Dari kelompok sedang VIII 7 dan VIII -2 Tanggungharjo. Dari kelompok rendah VIII -5 dan VIII -6. Sebelum penelitian dilakukan, antara kelompok eksperimen 1 dan kelompok eksperimen 2 diuji dengan uji-t berdasarkan nilai ujian tengah 
semester ganjil Kelas VIII bidang studi matematika.

Pada penelitian ini, metode yang digunakan dalam pengambilan data adalah metode angket, metode tes dan metode dokumentasi. Angket digunakan untuk mengetahui gaya belajar siswa, tes digunakan untuk mengetahui nilai prestasi belajar matematika siswa dan dokumentasi digunakan untuk mengetahui kemampuan awal siswa. Sebelum digunakan untuk mengambil data dalam penelitian, instrumen tes dan angket diuji terlebih dahulu dengan uji validitas dan reliabilitas untuk mengetahui kualitas tiap item. Untuk instrument tes, uji tersebut meliputi uji validitas isi, perhitungan daya beda dan indeks kesukaran serta uji reliabilitas. Untuk instrumen angket, uji tersebut meliputi uji validitas isi, perhitungan konsistensi internal dan uji reliabilitas.

$\begin{array}{rlr}\text { Pada } & \text { awal } & \text { penelitian } \\ \text { dilakukan } & \text { uji } & \text { prasyarat }\end{array}$ keseimbangan yaitu uji normalitas dan homogenitas nilai awal. Setelah semua prasyarat terpenuhi kemudian dilakukan uji keseimbangan dengan menggunakan analisis uji t. Selanjutnya pada nilai hasil penelitian dilakukan uji prasyarat analisis yang berupa uji normalitas dan uji homogenitas baru kemudian dilakukan uji hipotesis dengan analisis variansi dua jalan dengan sel tak sama. Setelah dilakukan uji hipotesis, bila perlu dilakukan juga uji lanjut pasca anava dengan melakukan uji komparasi ganda.

\section{HASIL PENELITIAN DAN PEMBAHASAN}

Uji keseimbangan dilakukan untuk mengetahui apakah sampel mempunyai kemampuan awal sama. Sebelum diuji keseimbangan, masing-masing sampel terlebih dahulu diuji apakah berdistribusi normal atau tidak, serta diuji apakah sampel berasal dari populasi yang homogen atau tidak.

Hasil dari uji normalitas kemampuan awal kelas eksperimen 1 dan kelas eksperimen 2 disajikan pada tabel berikut:

Tabel Hasil Uji Normalitas Kemampuan Awal

\begin{tabular}{|c|c|c|c|c|}
\hline UjiNormalitas & $\mathrm{L}_{\mathrm{obs}}$ & $\mathrm{L}_{0,05 ; \mathrm{n}}$ & Keputusan & Kesimpulan \\
\hline $\begin{array}{c}\text { Eksperimen 1 }(R M E) \\
\text { Eksperimen 2 (Problem } \\
\text { Posing) }\end{array}$ & 0,0826 & 0,0900 & Ho diterima & Normal \\
\hline
\end{tabular}

Berdasarkan tabel tersebut, untuk masing-masing sampel nilai dari $\mathrm{L}_{\mathrm{obs}}<\mathrm{L}_{0,05 ; \mathrm{n}}$, sehingga $\mathrm{H}_{0}$ diterima. Ini berarti bahwa masing- 
masing sampel berdistribusi normal. Selain uji normalitas, dilakukan juga uji homogenitas kemampuan awal. Hasil dari uji homogenitas kemampuan awal kelas eksperimen 1 dan kelas eksperimen 2 disajikan dalam tabel berikut:

Tabel Hasil Uji Homogenitas Kemampuan Awal

\begin{tabular}{|c|c|c|c|c|c|}
\hline Sampel & $\mathrm{k}$ & $\chi^{2} \mathrm{o} b s$ & $\chi^{2} 0,05 ; k-1$ & Keputusan & Kesimpulan \\
\hline Kelas & 2 & 2,528 & 3,841 & $\mathrm{H}_{0}$ diterima & Homogen \\
\hline
\end{tabular}

Berdasarkan tabel di atas, harga dari $\chi^{2}$ obs $<\chi^{2} \quad 0,05 ; \mathrm{k}-1$ sehingga dapat disimpulkan bahwa sampel berasal dari populasi yang homogen. Hasil uji keseimbangan dengan menggunakan uji-t diperoleh tobs $=0,00282$ dengan t0,025;184 = 1,96. Karena t0,025; $184<$ tobs < t0,025;184 maka H0 diterima. Ini berarti kelompok eksperimen 1 dan kelompok eksperimen 2 mempunyai kemampuan awal yang sama. Sehingga dapat ditarik kesimpulan bahwa kemampuan awal kedua kelompok populasi tersebut dalam keadaan seimbang. Instrumen yang diujicobakan dalam penelitian ini adalah tes prestasi belajar matematika siswa pada pokok bahasan kelipatan dan faktor dan angket yang digunakan untuk mengetahui gaya belajar siswa. Tes prestasi belajar matematika pada pokok bahasan kelipatan dan faktor terdiri dari 30 soal obyektif. Dari dua orang validator diperoleh bahwa 30 soal tes prestasi belajar dinyatakan valid karena telah memenuhi kriteria yang diberikan. Setelah dilakukan perhitungan daya pembeda dengan rumus korelasi produk momen diperoleh 24 soal yang daya pembedanya baik, yaitu dengan nilai rxy lebih besar dari 0,3. Sedangkan 4 soal yang daya pembedanya tidak berfungsi dengan baik adalah nomor 4, 27, 29, dan 30 karena nilai rxy dari 5 soal tersebut kurang dari 0,3. Dari 30 soal tes uji coba prestasi belajar matematika diperoleh 2 soal mudah, yaitu nomor 4 dan 13, sedangkan yang lainnya termasuk soal sedang, yang artinya tidak terlalu mudah dan tidak terlalu sukar. Reliabilitas dihitung dengan menggunakan rumus KR-20 diperoleh nilai dari = 0,814 . Karena $=0,814>0,7$ maka instrumen tes tersebut reliabel. Setelah dilakukan analisis terhadap 30 soal tes prestasi belajar matematika diperoleh 5 soal tidak dapat digunakan yaitu nomor 4, 13, 27, 29, dan 30. Sehingga peneliti hanya menggunakan 25 soal untuk melakukan penelitian.

\section{Pembahasan}

Angket gaya belajar siswa terdiri dari 40 soal obyektif. Dari dua 
orang validator diperoleh hasil bahwa 40 soal angket tersebut dinyatakan valid karena telah memenuhi kriteria yang diberikan. Angket yang diujicobakan terdiri dari 40 butir. Dari hasil perhitungan uji konsistensi internal dengan menggunakan rumus korelasi produk moment diperoleh nilai rxy dari 36 butir angket adalah lebih dari 0,3. Sedangkan 4 butir angket yang konsistensi internalnya kurang dari 0,3 adalah nomor 4, 11, 18, dan 31 . Dengan demikian, dari 40 butir angket yang ada, hanya 36 butir saja yang dapat digunakan untuk penelitian. Reliabilitas angket dihitung dengan rumus KR-20 diperoleh $=0,873$. Karena nilai dari $>0,7$ maka angket dinyatakan reliabel.

Berdasarkan kajian teori dan didukung dengan analisis variansi serta mengacu pada rumusan masalah yang telah diuraikan di awal, dapat disimpulkan bahwa:

a. Prestasi belajar matematika siswa yang diberi pembelajaran dengan pendekatan RME sama dengan siswa yang diberi pembelajaran dengan pendekatan Problem Posing.

b. Prestasi belajar matematika siswa yang mempunyai gaya belajar visual lebih baik dibandingkan siswa yang mempunyai gaya belajar auditorial, prestasi belajar siswa yang memiliki gaya belajar visual lebih baik dibandingkan siswa yang memiliki gaya belajar kinestetik dan prestasi siswa yang memiliki gaya belajar auditorial sama dengan siswa yang memiliki gaya belajar kinestetik.

c. Pada pembelajaran dengan pendekatan RME, siswa yang memiliki gaya belajar visual prestasi belajarnya sama dengan siswa yang memiliki gaya belajar auditorial, namun lebih baik daripada siswa yang memiliki gaya belajar kinestetik, siswa yang memiliki gaya belajar auditorial memiliki prestasi belajar yang sama dengan siswa yang memiliki gaya belajar kinestetik. Pada pembelajaran dengan pendekatan Problem Posing, semua gaya belajar memberikan prestasi belajar yang sama, baik gaya belajar visual, auditorial maupun kinestetik. Pada siswa dengan gaya belajar visual, pendekatan RME memberikan prestasi belajar yang lebih baik dibandingkan pendekatan Problem Posing. Pada siswa dengan gaya belajar auditorial maupun kinestetik, kedua pendekatan pembelajaran baik RME maupun Problem Posing memberikan prestasi belajar yang sama.

\section{SIMPULAN}

$\begin{array}{lcr} & \text { Hasil penelitian menunjukkan } \\ \text { bahwa pembelajaran } & \text { dengan } \\ \text { pendekatan } & \text { RME sama baiknya } \\ \text { dengan pembelajaran } & \text { dengan } \\ \text { pendekatan } & \text { Problem } & \text { Posing. } \\ \text { Sehingga pembelajaran RME dapat }\end{array}$


diterapkan pada proses belajar mengajar di kelas sebagai upaya meningkatkan prestasi belajar matematika siswa. Selain pendekatan pembelajaran, penelitian ini juga berkaitan dengan gaya belajar siswa. Siswa yang mempunyai gaya belajar visual akan memiliki prestasi belajar yang lebih baik dibandingkan dengan siswa yang memiliki gaya belajar kinestetik. Siswa dengan gaya belajar visual cocok dikenai pembelajaran dengan pendekatan RME, karena akan memberikan prestasi belajar yang lebih baik jika dibandingkan siswa dengan gaya belajar auditorial maupun kinestetik. Hasil dari penelitian ini dapat digunakan sebagai masukan bagi para guru untuk memperbaiki kualitas pelaksanakan proses pembelajaran sehingga prestasi belajar siswa dapat meningkat. Pembelajaran dengan pendekatan RME dan Problem Posing dapat dipakai oleh guru sebagai salah satu alternatif dalam pelaksanaan pembelajaran. Selain itu sebagai upaya meningkatkan prestasi belajar matematika siswa, guru juga harus memperhatikan faktor-faktor yang dapat mempengaruhi proses pembelajaran, diantaranya adalah gaya belajar siswa, pendekatan pembelajaran yang sesuai, sarana dan prasarana, kemampuan awal siswa, kondisi sosial ekonomi serta latar belakang keluarga dan lingkungan sekitar siswa.

\section{DAFTAR RUJUKAN}

Anonim. 2009. Statistika Dasar Untuk Penelitian Edisi Ke-2. Surakarta: Sebelas Maret University Press.

Peker, M. 2008. Pre-Service Elementary school Teachers' Learning Styles and Attitude towards Mathematics. Eurasia Journal of Mathematics, Science \& Technology Education, Vol. 4, No. 1, pg 21-26.

Sze, S. 2009. Learning Style and The Special Needs Child. Journal of Instructional Psychology; Vol. 36, No. 4; pg. 360-362.

Taiwei Ku, D dan Shen, C. 2009. Reliability, Validity and Investigation Of The Index of Learning Styles In A Chinese Language Version For Late Adolescents Of Taiwanese. Pro Quest Education Journals Vol. 44, No. 176; pg. 827-850.

Xia, X. Lü, C dan Wang, B. 2008. Research on Mathematics Instruction Experiment Based ProblemPosing. Journal of Mathematics Education. Vol. 1, No. 1, pg 153-163. 